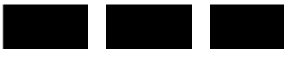 \\ am \\ THE WILLIAM DAVIDSON INSTITUTE \\ AT THE UNIVERSITY OF MICHIGAN
}

\section{Local Distributional Effects of Government Cash Transfers in Chile}

\author{
By: Claudio A. Agostini and Philip Brown
}

William Davidson Institute Working Paper Number 872

May 2007 


\title{
Local Distributional Effects of Government Cash Transfers in Chile
}

\author{
Claudio A. Agostini ${ }^{\mathrm{a}}$, Philip H. Brown ${ }^{\mathrm{b}, \mathrm{c}}$ \\ a Ilades-Universidad Alberto Hurtado, Santiago, Chile \\ ${ }^{b}$ Colby College, 5246 Mayflower Hill, Waterville, ME 04901, United States \\ ${ }^{c}$ International Food Policy Research Institute, 2033 K. St., NW, Washington, D.C. 20006, United States
}

May 2007

\begin{abstract}
Despite rapid economic growth and poverty reduction, inequality in Chile has remained high and remarkably constant over the last 20 years, prompting academic and public interest in the subject. Due to data limitations, however, research on inequality in Chile has concentrated on the national and regional levels. The impact of cash subsidies to poor households on local inequality is thus not well understood. Using povertymapping methods to asses this impact, we find heterogeneity in the effectiveness of regional and municipal governments in reducing inequality via poverty-reduction transfers, suggesting that alternative targeting regimes may complement current practice in aiding the poor.
\end{abstract}

JEL Codes: H53; 138; 054

Keywords: Inequality; Poverty Mapping; Subsidies; Targeting; Chile

\footnotetext{
*C.A. Agostini: agostini@uahurtado.cl; P.H. Brown: phbrown@colby.edu We thank Chris Elbers, Berk Özler and Gabriel Demombynes for multiple clarifications and discussions regarding the methodology employed in this analysis. We are also grateful to Jason Long for programming help and to iSciences for map design and support. Finally, we are grateful for financial support provided by the Universidad Alberto Hurtado and the Goldfarb Center for Public Affairs and Civic Engagement at Colby College.
} 


\section{Introduction}

Chile's economic growth may be characterised as being both rapid and sustained. Between 1986 and 2005, for example, GDP grew at an average rate of 6 per cent ${ }^{1}$ and real GDP per capita increased by 203 per cent, reaching US $\$ 8,569$ by $2006 .{ }^{2}$ Although the whole country grew at impressive rates, heterogeneity in the economic structure of individual regions largely determined local growth rates (Soto and Torche 2004). The engine underlying this dramatic economic performance was a series of economic reforms begun in the mid-1970s, many of which were deepened during the 1990s.

Although privatization and deregulation were the hallmarks of these reforms, poverty reduction was also an important policy objective beginning in the early 1980s, and gains against poverty have been as impressive as Chile's growth statistics. Using characteristics of housing to identify poor households, the government coupled housing subsidies with cash and in-kind transfers to the poor. Housing criteria were also used to identify locations for new schools and health care facilities. Chile thus took a multipronged approach to poverty reduction (Beyer 1997, Valdés 1999), and poverty rates fell from approximately 39.4 per cent in 1987 to 18.7 per cent in 2003; indigence rates also fell dramatically during this period, from approximately 14.2 per cent to 4.7 per cent.

Owing to Kuznets (1955), conventional wisdom holds that high or rising inequality is an unavoidable step in growth and development, yet governments with aggressive anti-poverty agendas should also be concerned about income distribution for its potential influence on growth. Foremost, there is little empirical evidence to support the Kuznets Hypothesis (Ravallion and Chen 1997, 2006). Moreover, although Brandolini and Rossi (1998) and Dollar and Kraay (2000) argue that growth and inequality are 
uncorrelated, there is mounting theoretical and empirical evidence that inequality has a negative effect on growth (Alesina and Rodrik, 1994; Persson and Tabellini, 1994;

Clarke, 1995; Deininger and Squire, 1996; Chen and Ravallion 2004). ${ }^{3}$ Inequality may also hinder efforts to reduce poverty directly. For example, Chen and Ravallion (2001) simulate the effect of income growth on global poverty rates between 1987 and 1998; holding inequality constant, poverty rates are predicted to be 1 percentage point lower than the empirical rates, suggesting that inequality limits poverty reduction. Similarly, Besley and Burgess (2003) estimate that a one standard deviation decrease in inequality would reduce poverty rates in Latin America by 45 per cent. Moreover, Ravallion (2001) finds that countries that experienced concurrent economic growth and falling inequality experienced much greater reductions in poverty than countries that had growth with rising inequality. Indeed, Kakwani (1993) demonstrates that for very high levels of income inequality, growth may result in higher subsequent poverty rates. Inequality measures from around the world have demonstrated convergence since the late 1980s (Ravallion 2003). Chile has defied these global trends, however, as inequality has remained high and constant between the late 1980 s and the early part of this decade (Contreras and Larrañaga 1999; Ferreira and Litchfield 1999; Contreras 2003). ${ }^{4}$ For example, official figures calculate the Gini coefficient to be 0.547 in 1987 and 0.546 in 2003 (Figure 1). Income inequality has been buoyed by limited migration (Soto and Torche 2004), uneven returns to education (Gindling and Robbins 2001), foreign competition in labor-intensive goods (Beyer, Rojas, and Vergara 1999), increased labor market participation among women (Contreras, Puentes, and Bravo, 
2005), and an increasing reliance on seasonal and fixed-contract labour (AmuedoDorantes 2005). ${ }^{5}$

National policies that target poverty reduction may also affect inequality. For example, appropriately-targeted cash subsidies to poor or indigent families may reduce both poverty and income inequality; Engel, Galetovic and Raddtaz (1999) demonstrate that targeted transfers are far more effective than progressive taxation schemes in reducing inequality at the national level. However, poverty-reduction programs may also have the opposite effect; as a case in point, improving the quality of education has been more effective in reducing poverty than expanding access to education (Chumbeco and Paredes 2005), yet the resulting disparities in access raise income inequality. Similarly, Chile's generous housing subsidies have been effective at reducing poverty, yet they have also had the undesirable effect of tying individuals to specific locations, thereby preventing migration to more productive areas with higher wages (Soto and Torche 2004).

Policy implementation may similarly affect inequality. ${ }^{6}$ From the theoretical perspective, decentralization in the administration of public goods may either decrease or increase inequality. On the one hand, local authorities have better information about local needs; on the other, they may be more susceptible to influence from vested interests and local elites (Bardhan and Mookherjee 2005). Indeed, there is evidence of subsidies for poverty alleviation being diverted under decentralised administration in Bangladesh (Galusso and Ravallion 2005), Ecuador (Araujo, et al. 2006), and elsewhere. By contrast, Aaberge and Langoren (2006) find that municipally-provided public services are distribution-neutral in Norway. Regardless, elite capture of funding 
for poverty alleviation is difficult to test because detailed income data that are representative at low levels of aggregation are not available for most countries. For this reason, analyses of inequality in Chile are typically undertaken at the national or regional level (e.g., Contreras 1996; Contreras and Ruiz-Tagle 1997; Contreras 2001; Pizzolito 2005) rather than at the level of municipalities or counties.

Such scarcity of localised income data has motivated research into methods for combining survey and census data in order to obtain geographically-disaggregated estimates of poverty and inequality. Using explanatory variables that are available in both a nationally-representative survey and the Ecuadorian census, Hentschel, et al. (1999) imputed income for every individual in the census, thereby allowing the estimation of geographically-disaggregated poverty rates. The statistical reliability of this method was improved by Elbers, Lanjouw and Lanjouw (2003), who incorporated errors from the first stage to obtain more precise estimates of income, and thus better estimates of poverty and inequality at the local level. This methodology has since been used to estimate wellbeing at the local level in Cambodia, Ecuador, Madagascar, Mozambique, South Africa, Tanzania and elsewhere (see, for example, Demombynes, et al. 2002; Elbers, et al. 2003; Elbers, et al. 2004; Demombynes and Özler 2005; Simler and Nhate 2005; Simler 2006; and Elbers, et al. 2007).

In this paper, we adapt this methodology to the Chilean context with the goal of assessing how government transfers to poor households affect inequality at the county level. We find that the effect of transfers on inequality varies considerably by region. In Regions IV, VII, VIII, IX, and X, for example, transfers that exceed the national average produce statistically-significant reductions (at the 0.01 level) in inequality in all but two of 
179 counties. Estimated inequality falls in 84 per cent of the counties in Regions III, V, and VI despite below-average to average transfers in these areas. In Regions I, II, and XII, very modest gains against inequality are perhaps not surprising given the low expected values of subsidies in these areas. Finally, Region XI sees very little reduction in inequality despite very high transfers, while inequality falls in $73 \%$ of counties in Region XIII despite having the lowest expected value of transfers. Taken together, these findings provide evidence that poverty-reduction transfers can have a sizable impact on local inequality in Chile, while suggesting that alternative targeting regimes may have greater impacts on poverty, at least in some locales.

The remainder of this paper is organised as follows: section 2 summarises the methodology; section 3 describes government programs for poverty reduction in Chile, including the various subsidies, as well as special features of the Chilean case; section 4 discusses the data used in the analysis; section 5 presents the empirical results; and section 6 concludes.

\section{Methodology}

The methodology proposed by Hentschel, et al (1999) and developed by Elbers, et al. (2003) takes advantage of the detail available in household surveys and the universal coverage of censuses. The intuition is conceptually straightforward: household income is estimated using survey data, restricting the explanatory variables to those also available in both the survey and a census undertaken at a similar point in time. These parameters are then used to estimate income for the entire population based on the 
census data. Finally, poverty and inequality indicators are estimated for geographic areas for which the census is representative but for which the survey is not.

The execution of the method is somewhat more complicated. We provide a brief overview here and a detailed accounting in Appendix 1; readers who are interested in the complete statistical properties of the estimators are referred to Elbers, et al (2003). First, a detailed household survey is used to estimate the joint distribution of household income and a vector of explanatory variables. Restricting the set of explanatory variables to those available in the census, these "first stage" estimates are then used to generate the distribution of income for any subgroup of the population, conditioning on the observed characteristics of that subgroup. The simplest means of estimating the model is to use a linear approximation of the conditional expectation, allowing geographic effects and heteroskedasticity into the distribution of the error term. It is important to note that the cluster component of the residual can significantly reduce the power of the estimates in the second stage, and that it is thus important to explain the variation in income due to location via observable variables to the greatest extent possible; stepwise regression is therefore used to derive the best-fitting specification for each of Chile's 13 regions.

The result of this first-stage estimation is a vector of coefficients, a variancecovariance matrix associated with this vector, and a set of parameters that describe the distribution of the errors. The second stage utilises this set of parameters along with the characteristics of the individuals or households in the census in order to generate predicted values of income and the relevant errors. For these effects, bootstrapping is used to simulate values of household income. The complete set of simulated values is 
then used to calculate the expected value of inequality for each subgroup. This procedure is repeated 250 times, taking a new set of coefficients and errors for each simulation; the mean and the standard deviations of the coefficients constitute the point estimates and the standard deviations for the inequality indicator, respectively.

Finally, the standard error of the inequality indicator must be estimated as accurately as possible in order to infer precise conclusions from the estimates. As shown in Appendix 1, the prediction error has three components: the first is given by the presence of a stochastic error in the first stage model, which implies that the actual income of the household deviates from its expected value (idiosyncratic error); the second is determined by the variance of the first stage parameter estimators (model error); and the third is given by the use of an inaccurate method to calculate the estimator of the inequality indicator (computation error). The idiosyncratic error falls proportionately with the size of the population in each area. This component of the error rises with lower levels of geographic disaggregation, limiting the extent of disaggregation possible. The model error is determined by the properties of the first stage estimators; its magnitude thus depends only on the precision of the first stage parameter estimates. For this reason, we made every effort to obtain the best fir in the first-stage regression. The computation error falls by increasing the number of simulations. Several papers that use this methodology specify 100 simulations. Despite the computationally-intensive simulation process, we specify 250 simulations to reduce this component of the error as much as possible. ${ }^{7}$ 


\section{Public Policy in Chile}

Beginning in the early 1980s, the government adopted a wide-ranging set of policies to reduce poverty. Central to the government's anti-poverty policy was the development of a standardised form (the "CAS Card," renamed the "CAS-2 Card" after revisions in 1987) to identify poor households on the basis of housing criteria, especially construction materials, housing density, access to potable water, and assets. ${ }^{8}$ Indeed, this form became the primary data point for setting government priorities in the provision of public housing, with the concentration of poor households in any given region in 1982 and 1992 directly influencing the allocation of housing subsidies over the subsequent decade (Soto and Torche 2004). Between 1990 and 2000, housing subsidies increased at an average rate of 10 per cent per year in real terms, and poor neighborhoods received additional subsidies to develop public sewerage and electric systems on the basis of these criteria. Although the efficacy of using housing criteria to identify beneficiaries of other social programs deserves scrutiny, these criteria were also used to identify locations for new schools and health care facilities as well as to identify indigent households to receive direct cash transfers.

Government subsidies to poor households fall into five main programs:

1. Family Subsidy (SUF): A subsidy provided to pregnant women, parents with children not covered by social security, and parents or guardians of persons with physical disabilities. To be eligible, beneficiaries must agree to take children under age 6 for regular medical checkups and to send children aged 6 to 18 years to school. Recipients are also automatically eligible for free access to public health services. The benefit totals $\mathrm{CH} \$ 4,126$ per month ${ }^{9}$ per recipient, and eligibility is determined by the CAS-2 Card.

2. Unemployment: A monthly payment for up to one year for unemployed workers who lost work through no fault of their own. The benefit decreases from $\mathrm{CH} \$$ 
17,338 the first 3 months to $\mathrm{CH} \$ 11,560$ the next three months and to $\mathrm{CH} \$ 8,669$ the last 6 months. Eligibility depends on formal employment for at least 52 weeks during the previous two years.

3. Assistance Pensions (PASIS): Pensions are provided for adults aged 65 and over, physically-disabled adults, and mentally-disabled individuals regardless of age who have a total income below half of the minimum pension allowance. Recipients are also automatically eligible for free access to public health services. The amount of each pension is $\mathrm{CH} \$ 45,091$ per month and twice that amount for mentally disabled. Eligibility is determined by the CAS-2 Card.

4. Solidarity Subsidy (Chile Solidario). A subsidy that targets indigent families and households with female heads. The subsidy takes the form of a monthly payment that decreases incrementally from $\mathrm{CH} \$ 10,500$ per month to $\mathrm{CH} \$ 4,126$ over two years. In addition, beneficiaries receive priority access to other subsidies for which they qualify. Eligibility is determined by the CAS-2 Card.

5. Water and Sewage Subsidy (SAP): A three-year, renewable subsidy to offset the cost of water among poor households. This subsidy covers between 20 per cent and 85 per cent of the cost of water for up to 15 cubic meters per month. There is no fixed amount for this subsidy, but the Ministry Finance sets the total number of subsidies in each region each year. Eligibility is determined by the CAS-2 Card and beneficiaries must be permanent residents of the housing unit.

Table 1 provides summary statistics for the number of recipients in each of Chile's 13 regions. Nearly 954,000 individuals (6.3 per cent of the population) receive the Family Subsidy each month. Almost 13 percent of the people living in Region IX benefit, while fewer than 2.3 per cent of households in region XII do. By contrast, only 3,682 individuals received Unemployment transfers each month on average, although this is at least partially due to the fact that the government replaced the transfer with mandatory unemployment insurance for those starting new jobs since 2002; this transfer is therefore cease to be a policy tool for addressing either poverty or inequality. The average monthly value of Unemployment payments is $\mathrm{CH} \$ 11,491$. Assistance Pensions dwarf the other subsidies, with an average benefit of $\mathrm{CH} \$ 45,059$. However, 
only 2.8 per cent of Chile's population receives these transfers. The distribution of this subsidy is similar to that of the Family Subsidy.

The Solidarity Subsidy and Water and Sewage Subsidy are provided to households rather than individuals. Approximately 1.1 per cent of households receive the former, with the greatest share in Regions III and VII. The average monthly value of the Solidarity Subsidy is $\mathrm{CH} \$ 9,842$. Finally, the Water and Sewage Subsidy is allocated to almost 16 per cent of households. The subsidy is particularly prevalent in the arid north of Chile (Regions I, II, III, and IV) and in Region XI. Fewer than 7 per cent of the households in Region XIII receive this subsidy. Moreover, unlike many other subsidies, the value of the Water and Sewage Subsidy varies by region, with beneficiaries in Regions I, II, and XI receiving far greater subsidies than households elsewhere, reflecting the cost of purchasing and transporting water in these areas. ${ }^{10}$ The average value of the subsidy varies from $\mathrm{CH} \$ 2,112$ in Region VII to $\mathrm{CH} \$ 7,316$ in Region II. Weighting household subsidies by the mean number of household members in each region, the total expected monthly value of all subsidies for a representative person ranges from $\mathrm{CH} \$ 966$ in Region XIII to $\mathrm{CH} \$ 3,595$ in Region XI; the national average is $\mathrm{CH} \$ 1708$.

As noted above, national, regional, and local policies that target poverty may also affect inequality. For example, cash subsidies to poor and indigent families are likely to reduce income inequality by raising incomes at the lower end of the distribution. Still, poor targeting or elite capture may moderate inequality reduction or, in some case, lead to increased inequality. Such factors may help to explain why Chile has seen virtually no progress against inequality despite rapid reductions in poverty through targeted 
programs (Figure 1). Indeed, the persistence of high inequality in Chile has emerged as an important issue of public debate ${ }^{11}$ and academic interest (e.g., Contreras 1996; Beyer 1997; Contreras and Ruiz-Tagle 1997; Valdés 1999; Contreras, et al. 2001).

\section{Data}

The survey employed to impute income as described above is the November 2003 National Survey of Socioeconomic Characterization (Casen), administered by the University of Chile on behalf of the Ministry of Planning (Mideplan). Unlike the national census, the Casen collects detailed income data for individuals and households, including cash transfers from the government. The survey also collects data on demographic characteristics of household members, living conditions, ownership of durable goods, access to sanitation, and health and education characteristics. Before these data are made available, the Economic Commission for Latin America and the Caribbean (ECLAC) undertakes a standardised procedure to correct for reporting errors and discrepancies with national accounts. ${ }^{12}$ These procedures are summarised in Appendix 2 and detailed fully in ECLAC, IPEA, and UNDP (2002).

The survey utilises multistage random sampling with regional stratification and clustering. In the first stage, the country is divided between rural and urban areas for each of the 13 regions, and the primary sampling units are selected with probabilities proportional to the population. The sampling frame of the Casen is based on the Population and Housing Census and by local records of new construction. In the second stage, households are selected into the sample with equal probability. ${ }^{13}$ The final sample includes 68,153 households comprising 257,077 people. These households 
represent 315 of the 342 counties in Chile, with as few as 49 and as many as 315 households surveyed in each county. Although Mideplan considers the Casen to be representative both at the regional level and at the level of the 301 self-reporting counties, there is no consensus with respect to representativeness at the county level; indeed, many scholars consider the Casen to be representative at the national and regional levels only (e.g., Valdés 1999; Contreras, et al. 2001; Pizzolito 2005).

Using the Casen alone to calculate inequality yields results that allow for few conclusions given the magnitude of the errors; for example, the estimated Gini coefficient for Region I is 0.495 , but with a standard error of 0.053 , the 95 per cent confidence interval is [0.392, 0.599]. Following the methodology proposed by Elbers, et al. (2003), Agostini and Brown (2007) demonstrate that imputing income from the 2003 Casen into the April 2002 census affords far more precise estimates of inequality.

The census covered 4,112,838 households composed of $15,545,921$ individuals. The data include demographic characteristics for the household members, living conditions, ownership of certain durable goods, access to sanitation, and health and education characteristics, but neither income nor consumption. A set of variables common to both the Casen and census is thus required to impute income. Although some explanatory variables are defined identically in both data sets, others were constructed. In such cases, the means and variances of the explanatory variables used in the analysis were evaluated to ensure that they measure the same thing. Using stepwise regression to detect the best fit for each region separately, we determined that household demographics (e.g., the number of household members; the share of young children in the household), characteristics of the household head (e.g., gender; 
education level; ethnicity), characteristics of the house itself (e.g., number of rooms; construction material; type of flooring; water source; sewerage), and asset ownership (e.g., washing machine; water heater; fixed telephone; cellular phone; satellite or cable television; microwave; computer; Internet access), were the strongest predictors of household income. Estimates also included location dummies to capture latent clusterlevel effects. The predictive ability of the model is high for cross-sectional data, with $R^{2}$ values for each region ranging between 0.36 and 0.52 ; complete summary statistics and the first stage results for each region are reported in Agostini and Brown (2007).

\section{Empirical Results}

Figures 2 through 6 depict estimated Gini coefficients for each county derived from the methodology described in Section II. In each, the left panel shows the estimated Gini coefficients based on income prior to the receipt of any transfers from the government. The right panel depicts estimated Gini coefficients for total income, including povertyreduction transfers. Darker shading indicates higher income inequality.

Based on these figures and on Table 2, it is evident that average pre-transfer income inequality is generally lowest for counties in central Chile, including Regions $\mathrm{V}$, $\mathrm{VI}$, and VII as well as the greater Santiago metropolitan area (Region XIII). Average county-level income inequality is higher in northern Chile (Regions I, II, III, and IV) and higher still south of Region VII. Regions VIII and XIII show the greatest variation in pretransfer income inequality at the county level. By contrast, variation is extremely low in Regions I, II, and III. 
Poverty-reduction transfers have a pronounced impact on estimated inequality at the county level in Regions VIII, IX, and X. Estimated reductions in inequality were quite modest in Regions II, V, VI, and XIII, perhaps not surprising given the relatively low levels of county-level income inequality in these areas to begin with. However, Region XII also displays extremely modest gains against county-level inequality despite displaying high inequality. Indeed, the estimated Gini coefficients before and after transfers are statistically different in only two of the 11 counties in Region XII at the 90 per cent confidence level and in none at the 99 per cent confidence level (Table 2). By contrast, every county in Regions IV, VII, IX, and X shows statistically significant differences in estimated inequality at the 99 per cent confidence level. Moreover, with the exception of Regions I, II, XI and XII, estimated inequality falls at the 99 per cent confidence level in at least 70 per cent of the counties in each region.

The 90 per cent confidence intervals for the whole country are depicted in Figure 7. In most cases, the confidence interval of the Gini when including transfers lies completely below the confidence intervals excluding transfers, implying a statistically significant reduction in inequality. For several counties, however, the confidence intervals overlap, implying improvements in inequality based on point estimates but not statistical significance. Overall, poverty-reduction transfers cause the estimated Gini coefficient to fall in 316 of Chile's 342 counties at the 90 per cent confidence level and in 288 counties at the 99 per cent confidence level.

A representative Chilean could expect to receive $\mathrm{CH} \$ 1,708$ per month in government subsidies in 2003 (Table 1), although this figure varies widely by region. If targeting is effective and if the benefits of these programs do accrue to the poor, then 
the greatest reductions in county-level poverty will occur in Regions IV, VII, VIII, IX, X, and $\mathrm{XI}$, where the expected value of transfers exceeds the national average by a wide margin. Clearly, this is the case for Regions IV, VII, IX, and X, in which transfers cause estimated inequality to fall at the 99 per cent confidence level in all counties. In Region VIII, estimated inequality falls in all but two of 52 counties at the 99 per cent confidence level. By contrast, transfers have comparatively little effect on inequality in Region XI, where only 60 per cent of counties see statistically significant (at the 99 per cent confidence level) reductions in inequality, suggesting that this area underperforms in terms of anticipated reductions in inequality. Expected transfers to a representative individual are close to the national average in Regions III and VI, and estimated inequality falls in 89 per cent and 88 percent of counties, respectively, suggesting that targeting is effective in these regions. The expected value of transfers is well below the national average in Regions I, II, V, XII, and XIII, resulting in very modest reductions in inequality. In Regions I, II, and V, for example, reductions in estimated inequality are significant at the 99 per cent confidence level in 60 per cent, 33 per cent, and 79 per cent of counties, respectively; in Region XII, transfers do not significantly affect inequality in any county at the 99 per cent confidence level. Finally, the expected value of transfers is lowest in Region XIII, yet estimated inequality falls significantly in 38 of the 52 counties, demonstrating that even small transfers may significantly impact inequality if appropriately targeted.

Table 3 depicts changes in inequality associated with poverty-reduction transfers by inequality quintile (ranked low to high). The table demonstrates considerable movement, with approximately 51 per cent of counties changing inequality cohorts as a 
result of the transfers. The most extreme change in inequality occurred in Pedro Aguirre Cerda (Region XIII), which fell from the $2^{\text {nd }}$ quintile to the $5^{\text {th }}$ quintile. Nevertheless, poverty-reduction transfers improve relative income inequality in 95 counties and reduce relative inequality in 73 , suggesting that the transfers reduce inequality on balance. Still, the effectiveness of poverty-reduction transfers in reducing inequality is clearly uneven.

Finally, to formally examine the impact of poverty-reduction transfers on income inequality at the national level, we estimate the non-parametric density of the countylevel Gini coefficients before and after transfers using the Epanechnikov Kernel estimator. The poverty-reduction transfers shift the distribution to the left (Figure 8), implying a reduction in inequality, and the Shapiro-Wilk test for normality strongly rejects the hypothesis that both distributions are normal. Moreover, the Kolmogorov-Smirnov test for equality of distribution functions rejects that the hypothesis that the two distributions come from the same data-generating process. ${ }^{14}$

\section{Conclusion}

The rapid economic growth that Chile has experienced since the 1980s has been accompanied by a rapid decline in poverty rates. Central to the government's success in alleviating poverty is a series of cash and in-kind transfers provided to pregnant women, female heads of household, the elderly, the handicapped, the unemployed, the indigent, poor parents, and those unable to purchase sufficient drinking water. Eligibility for each of these transfers except the unemployment subsidy (which has since been phased out) is determined by a standardised form that evaluates housing characteristics and household assets. 
Inequality, by contrast, has remained doggedly high, with the national Gini coefficient hovering around 0.55 since the late 1980 s. Contributing factors to the persistence of inequality include limited migration to highly productive areas, uneven returns to education, higher competition in labor-intensive sectors, higher labour force participation rates among women, and increasing reliance on fixed-contract labor. Cash transfers to poor, indigent, or vulnerable households can reduce income inequality by increasing the resources available to the lower end of the income distribution, but only if targeting is effective and if the incentive to generate autonomous income is not destroyed. That is, if transfers for poverty-alleviation fail to reach the poor, then income inequality may stagnate or even rise. Poor targeting may arise if the eligibility criteria for poverty-reduction transfers (i.e., housing characteristics and household assets) fail to accurately identify the poorest members of a community. It is also conceivable that government spending that is designated for poverty reduction may be misappropriated or captured by elites or pressure groups, particularly at the local level where government oversight may be limited.

Fortunately, theoretical advances in poverty-mapping proposed by Elbers, et al. (2003) allow income to be imputed with a high degree of statistical accuracy, even at very low levels of aggregation. These income estimates then allow us to assess the effect of cash transfers from the government for poverty reduction on local inequality. ${ }^{15}$ We find that poverty-reduction transfers reduce the estimated Gini coefficient at the 99 per cent confidence level in 288 of Chile's 342 counties. This is true of all 118 counties in Regions IV, VII, IX, and X and in all but seven of the 94 counties in Regions III, VI, and VIII. By contrast, just 15 of the 29 counties in Regions I, II, and XI 
saw statistically significant reductions in income inequality resulting from government transfers. None of the 11 counties in Region XII had statistically significant reductions in inequality with poverty-reductions transfers, although 30 of the 38 counties in Region $\mathrm{V}$ and 38 of the 52 counties in Region XIII did.

The expected monthly subsidy was higher than the national average in Regions IV, VII, VIII, IX, and X, suggesting that poverty-reduction transfers were well-targeted in these areas. However, the average subsidy was also higher than the national average in Region XI, which saw far more modest progress against inequality. Average transfers produced above-average reductions in inequality in Regions III and VI, while belowaverage transfers nevertheless produced significant reductions in estimated inequality in 76 per cent of the counties in Regions V and XIII. In Regions I, II, and XII, low subsidies had very little impact on inequality. These findings suggest that there exist considerable disparities in the effectiveness of poverty targeting across Chile, implying either that housing characteristics and asset ownership are flawed indicators of poverty or that government spending for poverty alleviation is being diverted to alternative purposes in some places. Policy options for better targeting therefore include revising the eligibility criteria and incorporating geographic considerations.

The Bachelet government has already taken important steps to better identify poor households by eliminating the CAS-2 card as the determinant of eligibility: because the CAS-2 Card emphasises housing and asset ownership in identifying the poor, it may have missed transitory poverty and may have penalised borderline households that had had improved their living conditions. Thus, effective April 2007, eligibility is based on the "Social Protection Card" (SPC), which evaluates households based on income stability, 
educational level, labour experience, age structure, disabilities, health status, number of people (including relative to the size of the housing unit), housing ownership, urban/rural location, and regional unemployment levels. The new criteria will likely therefore result in more effective targeting.

Although urban/rural status and regional unemployment levels are important considerations, there is nevertheless room to incorporate geography more fully to improve the targeting of cash transfers. Indeed, our results show considerable heterogeneity in both the level of inequality in individual counties and in the effectiveness of regional and municipal governments in reducing inequality via povertyreduction transfers; focusing on specific high-inequality counties where targeting has been poor may be an effective means of simultaneously reducing poverty and inequality. 


\section{Appendix 1}

This Appendix provides a brief overview of the methodology proposed by Hentschel, et al (1999) and developed by Elbers, et al. (2003). In the first stage, a model is created that relates the income per capita of household $h\left(Y_{h}\right)$ in cluster $c$ with a group of observable characteristics $\left(X_{h}\right)$ :

$$
\ln Y_{h c}=E\left[\ln Y_{h c} \mid X_{h c}\right]+u_{h c}=X_{h c} \beta+u_{h c}
$$

where the error vector $u$ is distributed $F(0, \Sigma)$. To allow correlation within each cluster, the error term is further assumed to consist of a cluster component $(\eta)$ and an idiosyncratic error $(\varepsilon)$ :

$$
u_{h c}=\eta_{c}+\varepsilon_{h c}
$$

The two components are assumed to be independent of each other and uncorrelated with the observable variables $X_{h c}$.

It is not necessary to specify a restrictive functional form for the idiosyncratic component of the error, $\sigma_{\varepsilon}^{2}$. Indeed, with consistent estimators of $\beta$, the residuals of the decomposition of the estimated error,

$$
\hat{u}_{h c}=\hat{u}_{. c}+\left(\hat{u}_{h c}-\hat{u}_{. c}\right)=\hat{\eta}_{c}+\hat{\varepsilon}_{h c}
$$

can be used to estimate the variance of $\varepsilon .{ }^{16}$ The functional form commonly used for estimating the variance of the idiosyncratic error is:

$$
\sigma_{\varepsilon}^{2}=\left[\frac{A \hat{\varepsilon}^{z_{h c}^{T} \alpha}+B}{1+\hat{\varepsilon}^{z_{h c}^{T} \alpha}}\right]
$$

The upper and lower limits, $A$ and $B$, can be estimated together with the parameter $\alpha$ using the standard pseudo-maximum likelihood; the advantage of this approach is that it eliminates negative and excessively high values for the predicted variances. 
The simplest means of estimating the model is to use a linear approximation of the conditional expectation, allowing geographic effects and heteroskedasticity into the distribution of the error term. It is important to note that the cluster component of the residual can significantly reduce the power of the estimates in the second stage, and that it is thus important to explain the variation in income or consumption due to location via observable variables to the greatest extent possible.

The result of this first-stage estimation is a vector of coefficients, $\beta$, a variancecovariance matrix associated with this vector, and a set of parameters that describe the distribution of the errors. The second stage utilises this set of parameters along with the characteristics of the individuals or households in the census in order to generate predicted values of the log of income and the relevant errors. For these effects, bootstrapping is used to simulate values of income of each household or each individual. These simulated values are based on the prediction of the income and the error terms, $\eta$ and $\varepsilon$ :

$$
\hat{Y}_{h c}=\exp \left(X_{h c} \hat{\beta}+\hat{\eta}_{c}+\hat{\varepsilon}_{h c}\right)
$$

For each household, the two components of the error term are taken from the empirical distribution described by the parameters estimated in the first stage. The coefficients $\hat{\beta}$ are taken from a normal multivariate distribution described by the estimators of $\beta$ in the first stage and the associated variance-covariance matrix. The complete set of simulated values of $\hat{Y}_{h c}$ is then used to calculate the expected value of poverty or inequality measures by area. This procedure is repeated $n$ times, taking a new set of coefficients $\beta$ and errors for each simulation; for each geographic area, the mean and the standard deviation of the inequality indicator are calculated over the 
whole set of simulations, which constitute its point estimate and its standard deviation, respectively.

We will call the inequality indicator $G\left(n_{c}, X_{c}, \beta, u_{c}\right)$, where $n_{c}$ is a $N_{c}$ vector of the number of household members in county $c, X_{c}$ is a $N_{c} x k$ vector of their observable characteristics, and $u_{c}$ is a $N_{c}$ error vector. Thus, the expected value of the inequality indicator is estimated given the characteristics of the individuals and the households and the model estimated in the first stage, i.e.:

$$
G_{c}^{E}=E[G \mid n, X ; \xi]
$$

where $\xi$ is the vector of parameters of the model, including the parameters that describe the distribution of the error term. Replacing the unknown vector $\xi$, with a consistent estimator $\hat{\xi}$, we get:

$$
G_{c}^{E}=E[G \mid n, X, \hat{\xi}]
$$

This conditional expected value is generally impossible to resolve analytically, making it necessary to use Monte Carlo simulations to obtain an estimator, $\widetilde{G}_{c}^{E}$.

One complication associated with this methodology is calculating the correct standard errors, which is not trivial. Because it is not possible to calculate them analytically, the methodology again resorts to bootstrapping techniques and Monte Carlo simulations. Suppressing the subscripts, the difference between the estimator of the expected value of $G, \widetilde{G}_{c}^{E}$, and the actual level of the inequality indicator for the geographic area can be decomposed into:

$$
G-\widetilde{G}^{E}=\left(G-G^{E}\right)+\left(G^{E}-\hat{G}^{E}\right)+\left(\hat{G}^{E}-\widetilde{G}^{E}\right)
$$


The prediction error thus has three components: the first is due to the presence of a stochastic error in the first stage model, implying that the actual household incomes deviate from their expected values (idiosyncratic error); the second is due to the variance in the estimators of the parameters of the model from the first stage (model error); and the third is due to the use of an inexact method to calculate $\hat{G}_{c}$ (computation error).

The variance of the estimator due to the idiosyncratic error shrinks proportionally with the population in each geographic area. Thus, smaller populations within each geographic area are associated with larger idiosyncratic errors, introducing a limit to the extent of disaggregation that may be achieved. The variance of the estimator due to the model error can be calculated using the delta method:

$$
V_{\text {Model }}=\nabla^{T} V(\hat{\xi}) \nabla
$$

where $\nabla=\left[\partial G^{E} / \partial \xi\right], V(\xi)$ is the variance-covariance matrix of the first stage estimators, and $\hat{\xi}$ is a consistent estimator of $\xi$, also obtained from the first stage. This component of the predicted errors is determined by the properties of the first-stage estimators and therefore doesn't systematically change with the population in each geographic area; its magnitude depends only on the precision of the first-stage estimates. The variance of the estimator due to computational error depends on the computational methodology used. Since Monte Carlo simulations are employed here, it is possible to reduce this error component by increasing the number of simulations; we use 250 simulations to minimise the error component to the greatest extent possible.

The expected value of the inequality indicator coefficient is thus conditional on the first stage regression, the variance due to the idiosyncratic component of income 
per capita of the households, and the gradient vector. The Monte Carlo simulation generates 250 vectors of error terms from the distribution estimated in the first stage. With each set of vectors, the inequality indicator is calculated. Then, the expected value simulated for the inequality indicator is the average of the 250 responses:

$$
\widetilde{G}^{E}=\frac{1}{250} \sum_{d=1}^{250}\left(\hat{G}_{d}^{E}\right)
$$

The variance of $G$ is estimated using the same simulated values as:

$$
V_{\text {Model }}=\frac{1}{250} \sum_{d=1}^{250}\left(G_{d}-\widetilde{G}^{E}\right)^{2}
$$

Finally, it is important to underscore the crucial assumption that the models estimated using survey data are applicable to the observations of the census. This assumption is reasonable enough if the year of the census and the survey coincide or are close. In the case of this particular study, the 2002 census is matched with the 2003 Casen survey, making the assumption implicit in the methodology reasonable. 


\section{Appendix 2}

This Appendix describes the adjustments to the Casen undertaken by ECLAC. See also ECLAC, IPEA, and UNDP (2002).

The first type of adjustment made by ECLAC is related to non-response and invalid answers. In particular, ECLAC makes adjustments in three cases: people who declare themselves as employed but who do not report income from their main occupation; people who declared themselves to be retired or living on a pension but who do not report the amount of the pension; and households living in owner-occupied housing but who do not report an imputed rental value. In the first and second case, ECLAC imputes to each employed and retired person the value of the mean income reported by people of similar characteristics. ${ }^{17}$ In the third case, ECLAC imputes an implicit rental value using the "hot deck" technique, wherein the data set is ordered geographically and households are selected based on the housing tenancy situation, the type of housing and other household characteristics. By contrast, when households report a positive value for imputed rent despite not being owners, the value reported is subtracted from the household income.

The second type of adjustment made by ECLAC is related to under or over reporting of some types of income. The procedure followed to correct for misreporting basically consists in adjusting income from some specific sources to match the corresponding value in the national accounts. Specifically, the adjustment is made to match the aggregate income of the Households and Expenditures Account of the National Accounts System of the Central Bank of Chile. To do this, the data from National Accounts is converted to match the income categories included in the Casen. 
Then, the total values by each specific income category are compared to the ones in the Casen (using expansion factors). Finally, the proportional differences for each income category are imputed uniformly to each individual receiving income in the Casen. There are two exceptions to this last step: adjustments to capital income are made only to the top quintile of households, and income from transfers and gifts are not adjusted at all. 


\section{Notes}

${ }^{1}$ There are two distinct periods for Chile's growth between 1986 and 2005: during the period 1986-1996, the average growth rate was $8 \%$; during the period $1997-2005$, it slowed to $4 \%$.

${ }^{2}$ GDP per capita reached $\$ 12,737$ in purchasing power parity (PPP) terms.

${ }^{3}$ Interestingly, Aghion, Caroli, and Garcia-Penalosa (1999) suggest that higher inequality may positively impact subsequent growth in the presence of credit market failures. In particular, with decreasing marginal product of capital, the output loss from incomplete credit markets will rise with the proportion of poor in the economy.

${ }^{4}$ Indeed, inequality has been high for much longer; Larrañaga (2001) estimates the Gini coefficient for metropolitan Santiago to be between 0.47 and 0.57 from 1958 through 2001.

${ }^{5}$ Given these characteristics of the Chilean economy, it is perhaps not surprising that income mobility is also quite low (Chumacero and Paredes 2005).

${ }^{6}$ Of course, local inequality may causally affect poverty at the local level as well, especially through its impact on health, education, and the incidence of crime and violence (Deaton 2001).

${ }^{7}$ There are no significant gains in efficiency by further increasing the number of repetitions.

${ }^{8}$ Soto and Torche (2004) provide additional details on the CAS form and the criteria for poverty it formalizes. Officially-designated poor households are re-evaluated every three years for eligibility.

${ }^{9}$ In 2003, US\$ $1=\mathrm{CH} \$ 691.4$ on average.

${ }^{10}$ For example, the cost of drinking water is up to 66 per cent higher than the national average in Region $\mathrm{XI}$ despite heavy rainfall in the area.

${ }^{11}$ To wit, each of the three main candidates addressed the issue extensively during the 2006 presidential campaign. In addition, inequality was the explicit focus of one of the presidential debates.

${ }^{12}$ Although the ECLAC adjustments could theoretically introduce bias, Contreras and Larrañaga (1999) present evidence to the contrary. Regardless, the unadjusted data are not available.

${ }^{13}$ Further methodological details are provided by Pizzolito (2005) and http://www.mideplan.cl/casen/pdf/Metodologia_\%202003.pdf

${ }^{14}$ The first step of the test does not reject the hypothesis that the distribution of Gini coefficients for total income contains smaller values than the distribution of Gini coefficients for autonomous income. The second step of the test rejects the hypothesis that the distribution of Gini coefficients for total income contains larger values than the distribution of Gini coefficients for autonomous income. As a result, the joint test rejects the hypothesis that the two distributions are equal.

${ }^{15}$ Unfortunately, it is not feasible to asses the effect of in-kind transfers provided by the government, because the values of these transfers are not specified in the survey data.

${ }^{16}$ The subindex "." in the equation represents the average over the index.

${ }^{17}$ In the case of employed persons, six variables are used match characteristics: family relationship, gender, educational level, occupational category, type of economic activity and region. In the case of retired person, only the first three variables are used. 


\section{References}

Aaberge, Rolf and Audun Langørgen. 2006. "Measuring the Benefits from Public Services: The Effects of Local Government Spending on the Distribution of Income in Norway." Review of Income and Wealth 52(1): 61-83.

Aghion, Philippe Eve Carola, and Cecilia Garcia-Penalosa. 1999. "Inequality and Economic Growth: The Perspective of New Growth Theories." Journal of Economic Literature 37(4): 1615-1660.

Agostini, Claudio and Philip H. Brown. 2007. "Desigualdad Geográfica en Chile." Forthcoming, Revista de Análisis Económico.

Alesina, Alberto and Dani Rodrik. 1994. "Distributive Politics and Economic Growth." Quarterly Journal of Economics 108: 465-490.

Amuedo-Dorantes, Catalina. 2005. "Wage Contracts and Earnings Inequality: The Case of Chile." Journal of Development Studies 41(4): 589-616.

Araujo, M. Caridad, Francisco H.G. Ferreira, Peter Lanjouw, and Berk Özler. 2006. "Local Inequality and Project Choice: Theory and Evidence from Ecuador." World Bank Policy Research Paper No. 3997.

Bardhan, Pranab and Dilip Mookherjee. 2005. "Decentralizing Antipoverty Program Delivery in Developing Countries." Journal of Public Economics 89: 675-704.

Besley, Timothy and Robin Burgess. 2003. "Halving Global Poverty." Journal of Economic Perspectives 17(3): 3-22.

Beyer, Harald 1997. "Distribución del Ingreso: Antecedentes para la Discusión”. Estudios Públicos 65: 558.

Beyer, Harald, Patricio Rojas, and Rodrigo Vergara, 1999, "Trade Liberalization and Wage Inequality." Journal of Development Economics 59(1): 103-123.

Brandolini, Andrea and Nicola Rossi. 1998. "Income Distribution and Growth in Industrial Countries." In Vito Tanzi and Ke-young Chu, eds., Income Distribution and High-Quality Growth. Cambridge, MA: MIT Press.

Chen, Shauhua and Martin Ravallion. 2001. "How Did the World's Poorest Fare in the 1990s?" Review of Income and Wealth 47(3): 283-300.

Chen, Shauhua and Martin Ravallion. 2004. "How Have the World's Poorest Fared Since the Early 1980s?" World Bank Research Observer 19(2): 141-170.

Clarke, George R.G. 1995. "More Evidence on Income Distribution and Growth." Journal of Development Economics 47: 403-428.

Chumacera, Rómulo A. and Ricardo D. Paredes. 2004. "Characterizing Income Distribution for Poverty and Inequality Analysis." Estudios de Economía 32(1): 97-117.

Contreras, Dante. 1996. "Pobreza y Desigualdad en Chile: 1987-1992. Discurso, Metodología y Evidencia Empírica." Estudios Públicos 64: 57-94.

Contreras, Dante. 2001. "Economic Growth and Poverty Reduction by Region: Chile 1990-96." Development Policy Review 19(3): 291-302. 
Contreras, Dante. 2003. "Poverty and Inequality in a Rapid Growth Economy: Chile 1990-96." Journal of Development Studies 39(3): 181-200.

Contreras, Dante and Osvaldo Larrañaga. 1999. "Activos y Recursos de la Población Pobre en Chile." El Trimestre Económico 66(263): 459-500.

Contreras, Dante, Osvaldo Larrañaga, Julie Litchfield and Alberto Valdés. 2001. "Poverty and Income Distribution in Chile 1987-1998: New Evidence." Cuadernos de Economía 114: 191-208.

Contreras, Dante, Esteban Puentes, and David Bravo. 2005. "Female Labor Force Participation in Greater Santiago, Chile: 1957-1997. A Synthetic Cohort Analysis." Journal of International Development 17(2): 169-186.

Contreras, Dante and Jaime A. Ruiz-Tagle. 1997. "Como Medir la Distribución del Ingreso en Chile." Estudios Públicos 65: 59-80.

Deaton, Angus. 2001. "Inequalities in Income and Inequalities in Health." In Finis Welch, ed. The Causes and Consequences of Increasing Inequality. Chicago: The University of Chicago Press.

Deininger, Klaus and Lyn Squire. 1998. "New Ways of Looking at Old Issues: Inequality and Growth." Journal of Development Economics 57(2): 259-287

Demombynes, Gabriel, Chris Elbers, Jean Lanjouw, Peter Lanjouw, Johan Mistiaen and Berk Özler. 2002. "Producing an Improved Geographic Profile of Poverty." World Institute for Development Economics Research Discussion Paper No. 2002-39.

Demombynes, Gabriel and Berk Özler. 2005. "Crime and Local Inequality in South Africa." Journal of Development Economics 76(2): 265-292.

Dollar, David and Aart Kraay. 2002. "Growth is Good for the Poor." Journal of Economic Growth 7(3): 195-225.

Economic Commission for Latin America and the Caribbean, Instituto de Pesquisa Econômica Aplicada, and United Nations Development Program. 2002. Meeting the Millennium Poverty Reduction Target in Latin America and the Caribbean. Santiago: ECLAC.

Elbers, Chris, Tomoki Fujii, Peter Lanjouw, Berk Özler, and Wesley Yip. 2007. "Poverty Alleviation Through Geographic Targeting: How Much Does Disaggregation Help?" Journal of Development Economics. 83(2007): 198-213.

Elbers, Chris, Jean O. Lanjouw, and Peter Lanjouw. 2003 "Micro-Level Estimation of Poverty and Inequality." Econometrica 71(1): 355-364.

Elbers, Chris, Peter Lanjouw, Johan Mistiaen, Berk Özler and Kenneth Simler. 2003. "Are Neighbours Equal?" World Institute for Development Economics Research Discussion Paper No. 2003-52.

Elbers, Chris, Peter Lanjouw, Johan Mistiaen, Berk Özler and Kenneth Simler. 2004. "On the Unequal Inequality of Poor Communities." World Bank Economic Review 18(3): 401-421.

Engel, Eduardo, Alexander Galetovic and Claudio Raddatz (1999), "Taxes and Income Distribution in Chile: Some Unpleasant Redistributive Arithmetic", Journal of Development Economics 59(1): 155192.

Ferreira, Francisco H.G. and Julie A. Litchfield. 1999. "Calm after the Storms: Income Distribution and Welfare in Chile 1987-1994." World Bank Economic Review 13(3): 509-538. 
Galasso, Emanuela and Martin Ravallion. 2005. "Decentralized Targeting of an Antipoverty Program." Journal of Public Economics 89: 705-727.

Gindling, T.H. and Donald Robbins. 2001. "Changes and Patterns of Changing Wage Inequality in Chile and Costa Rica During Structural Adjustment." World Development 29(4): 725-745.

Hentschel, Jesko, Jean O. Lanjouw, Peter Lanjouw, and Javier Poggi. 2000. "Combining Census and Survey Data to Trace the Spatial Dimensions of Poverty: A Case Study from Ecuador." World Bank Economic Review 14(1); 147-165.

Kakwani, Nanak. 1993. "Poverty and Economic Growth with Application to Cote D'Ivoire." Review of Income and Wealth 39: 121-139.

Kuznets, Simon. 1955. "Economic Gorwth and Income Inequality." American Economic Review 45(1): 128.

Larrañaga, Osvaldo (2001), “Distribución de Ingresos en Chile: 1958-2001”, Documento de Trabajo No. 178, Departamento de Economía, Universidad de Chile.

Persson, T. and G. Tabellini. 1994. "Is Inequality Harmful for Growth?" American Economic Review 84: 600-621.

Pizzolito, Georgina 2005. "Poverty and Inequality in Chile: Methodological Issues and a Literature Review." CEDLAS Working Paper No. 20.

Ravallion, Martin. 2001. "Growth, Inequality, and Poverty: Looking Beyond Averages." World Development 29(11): 1803-1815.

Ravallion, Martin. 2003. “Inequality Convergence." Economics Letters 80(2003): 351-356.

Ravallion, Martin and Shaohua Chen. 1997. "What Can New Survey Data Tell Us About Recent changes in Poverty and Distribution?" World Bank Economic Review 11(2): 357-382.

Ravallion, Martin and Shaohua Chen. 2006. "China's (Uneven) Progress Against Poverty." Journal of Development Economics 82: 1-42.

Simler, Kenneth R. 2006. "Nutrition Mapping in Tanzania: An Exploratory Analysis." International Food Policy Research Institute, FCND Discussion paper 204.

Simler, Kenneth R. and Virgulino Nhate. 2005. "Poverty, Inequality, and Geographic Targeting: Evidence from Small-Area Estimates in Mozambique." International Food Policy Research Institute, FCND Discussion Paper 192.

Soto, Raimundo and Arístides Torche. 2004. "Spatial Inequality, Growth, and Migration in Chile." Cuadernos de Economía 41: 401-424.

Valdés, Alberto (1999), "Pobreza y Distribución del Ingreso en una Economía de Alto Crecimiento: Chile, 1987-1995", Estudios Públicos 75: 5-47. 
Figure 1. Income Inequality and Poverty in Chile: 1987-2003

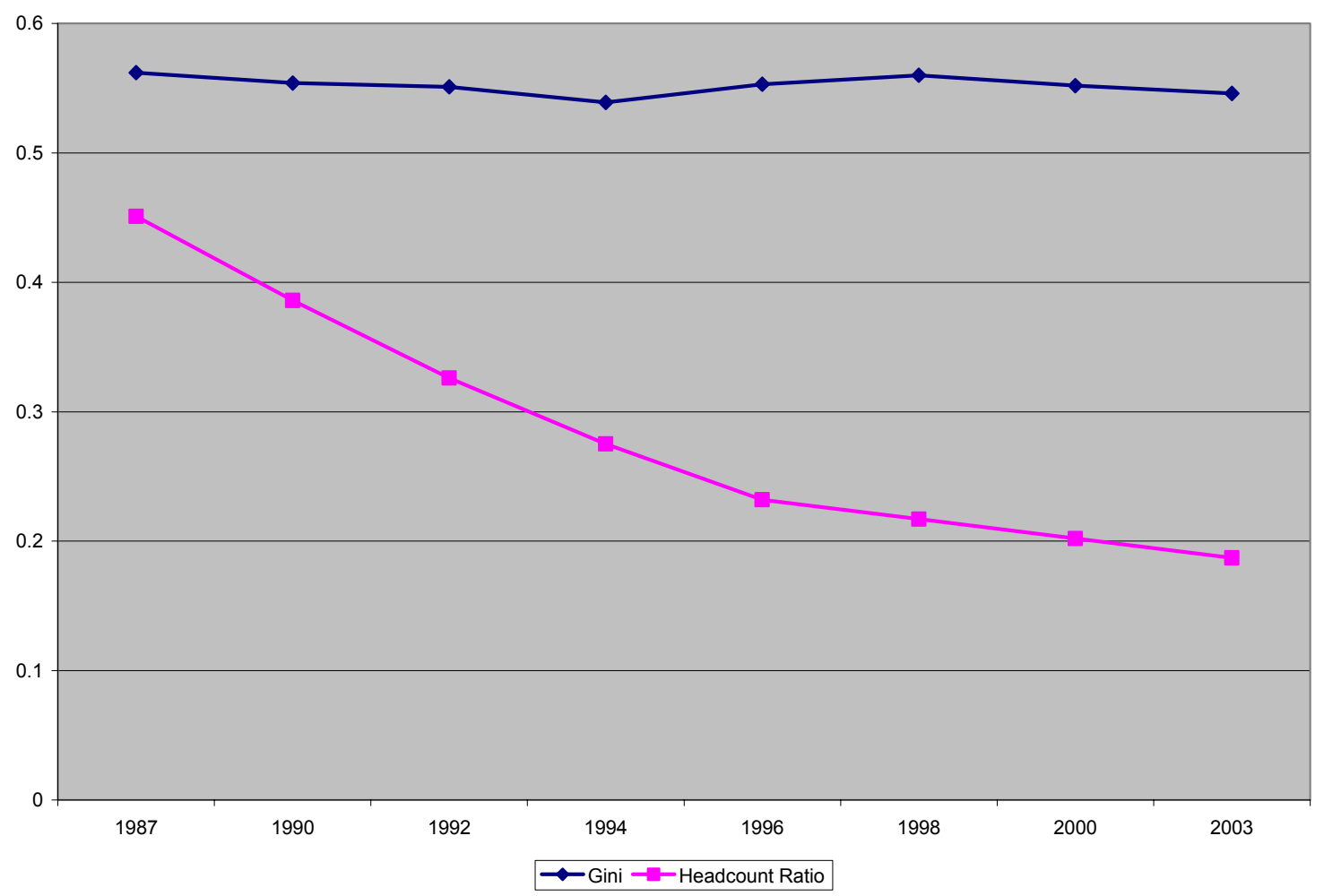

Figure 2. Pre- and Post-Transfer Gini Coefficients in Northern Chile (Regions I, II, III, \& IV)

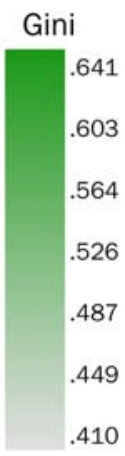

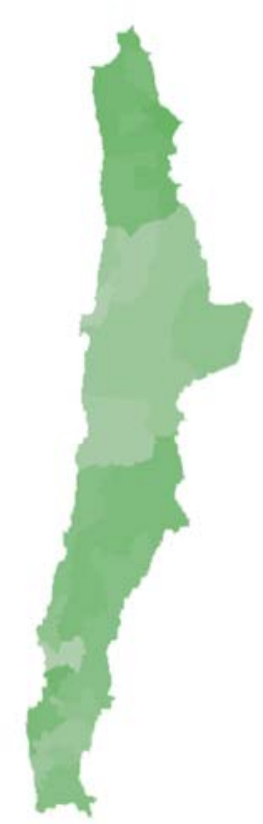

Pre-Transfers

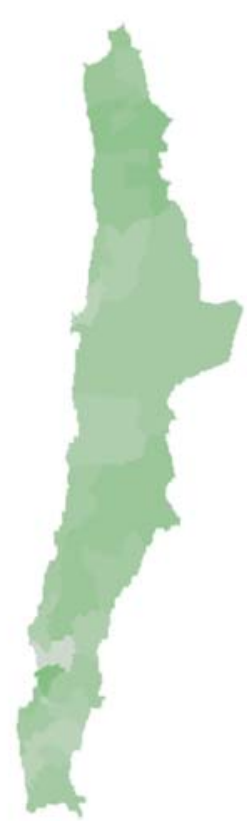

Post-Transfers 
Figure 3. Pre- and Post-Transfer Gini Coefficients in Santiago and Valparaiso (Regions V \& XIII)

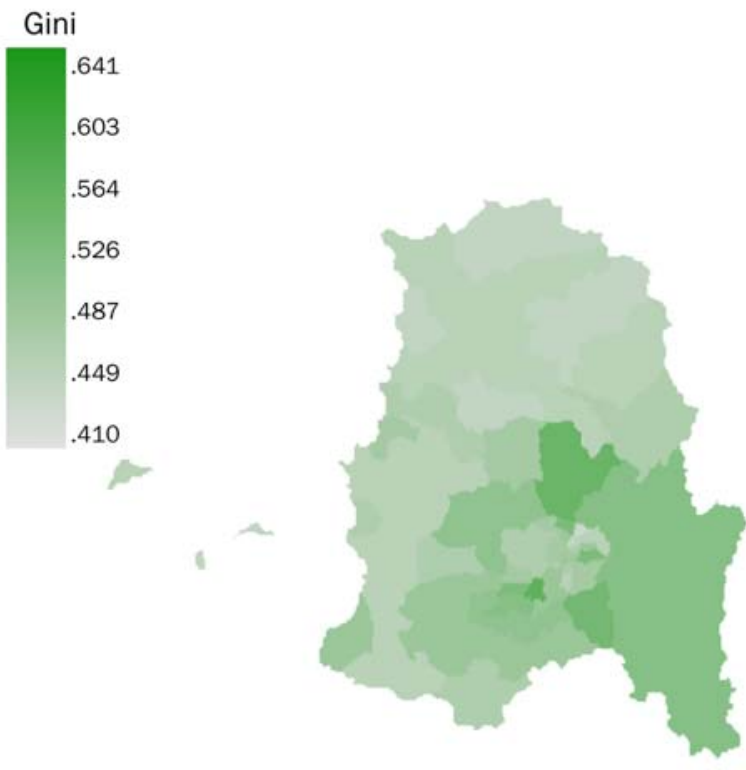

Pre-Transfers

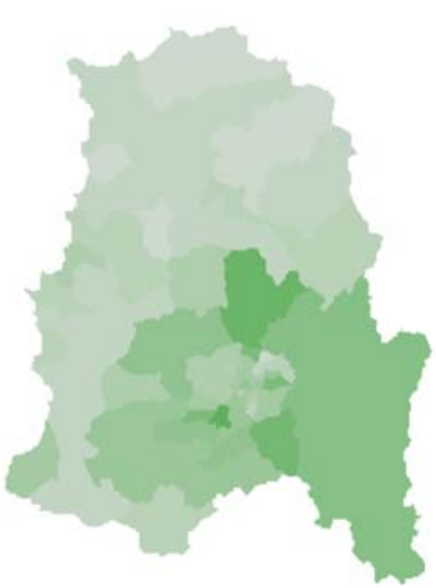

Post-Transfers

Scale: $1: 4,950,000$

Figure 4. Pre- and Post-Transfer Gini Coefficients in Central Chile (Regions VI, VII, \& VIII)

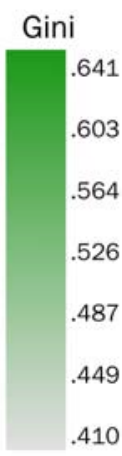

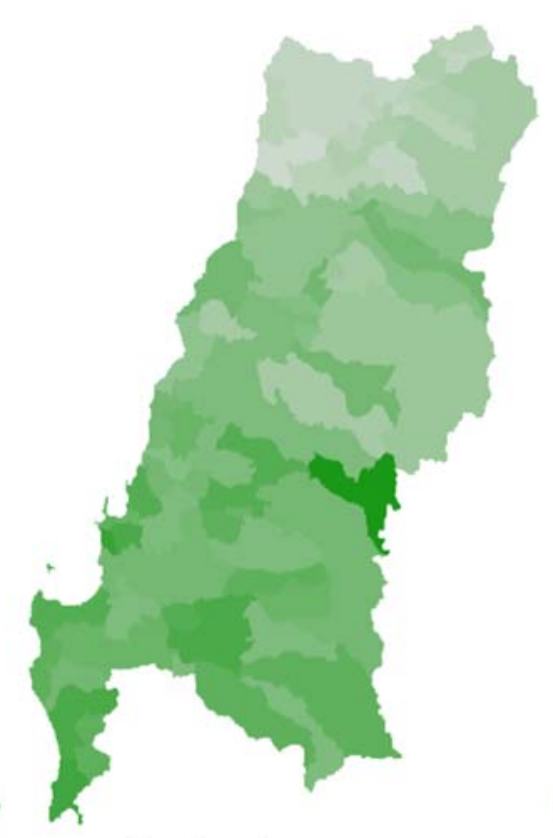

Pre-Transfers

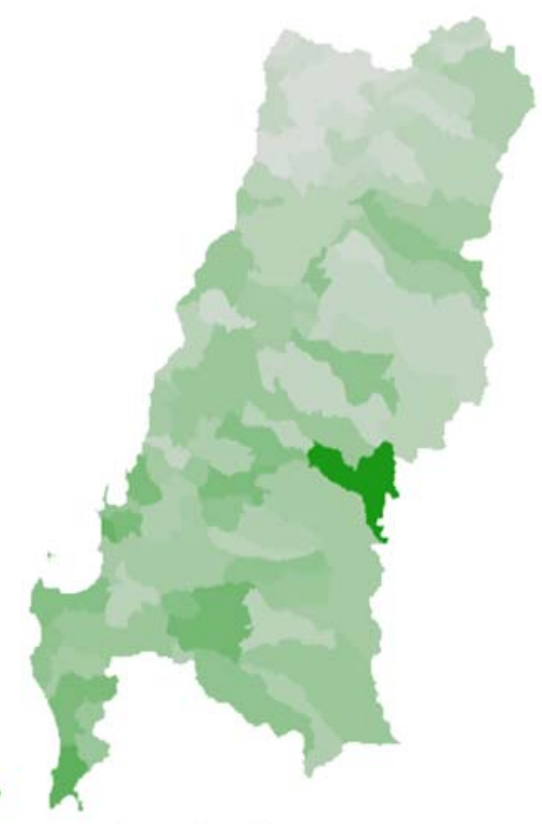

Post-Transfers 
Figure 5. Pre- and Post-Transfer Gini Coefficients in Southern Chile (Regions IX \& X)

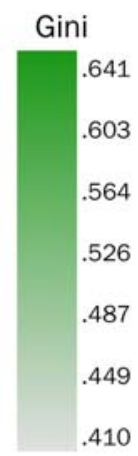

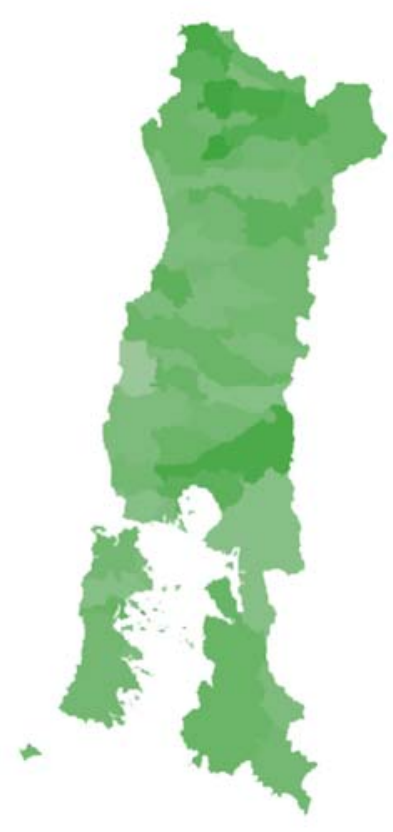

Pre-Transfers

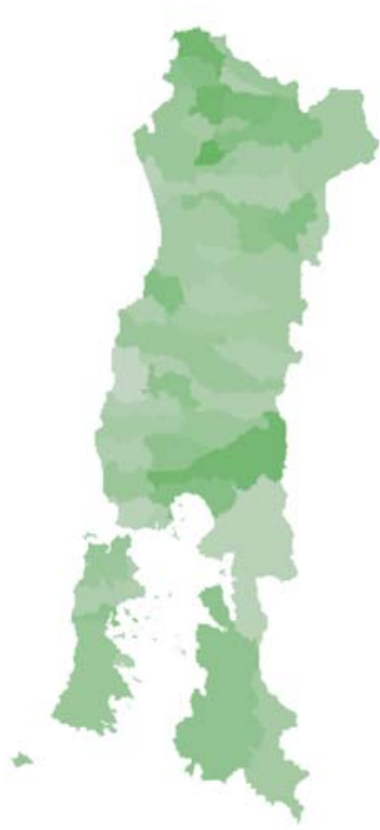

Post-Transfers

Figure 6. Pre- and Post-Transfer Gini Coefficients in Chilean Patagonia (Regions XI \& XII)

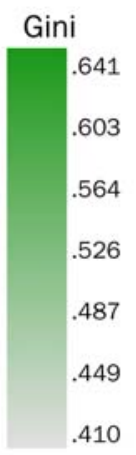

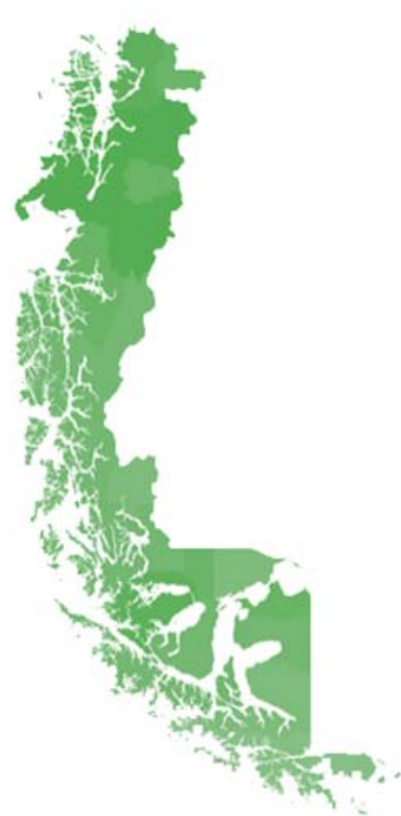

Pre-Transfers

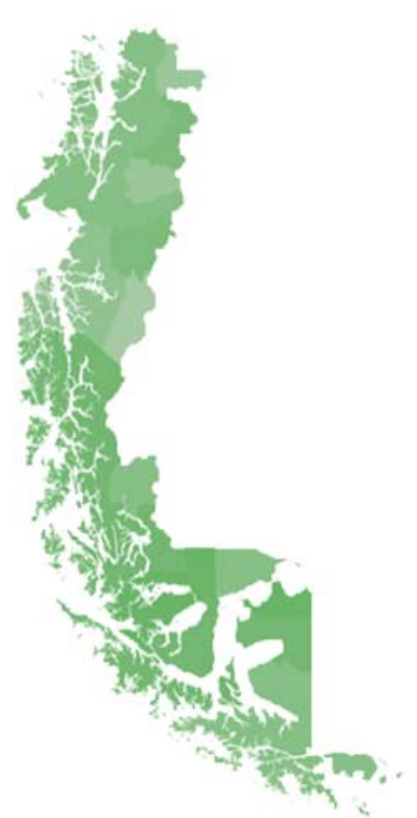

Post-Transfers 
Figure 7. 90 per cent Confidence intervals for Pre-Transfer Gini (Blue) and Post-Transfer Gini (Yellow)

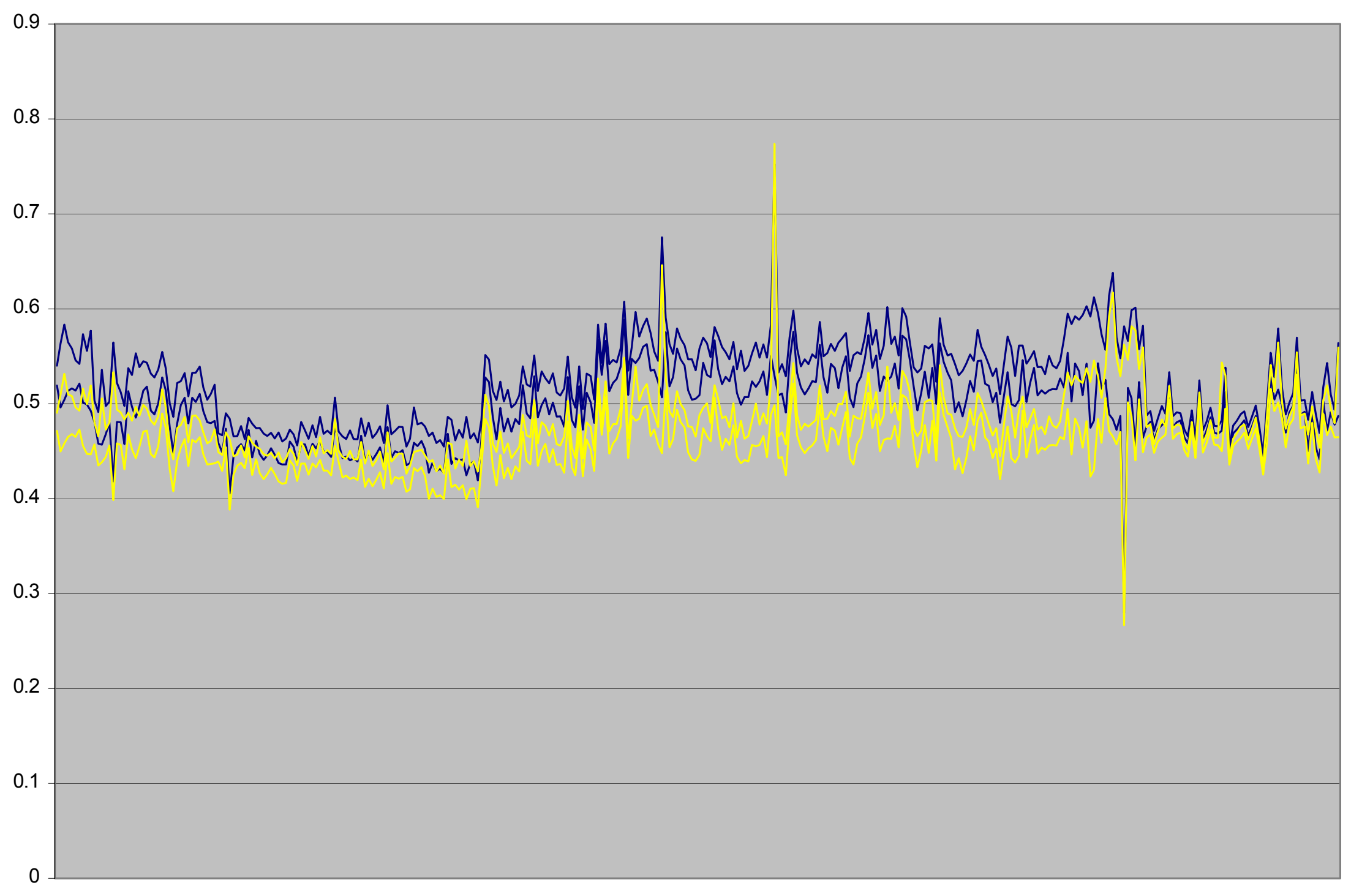


Figure 8. Epanechnikov Kernal Estimation of the Nonparamtric Density of Estimated Gini Coefficients

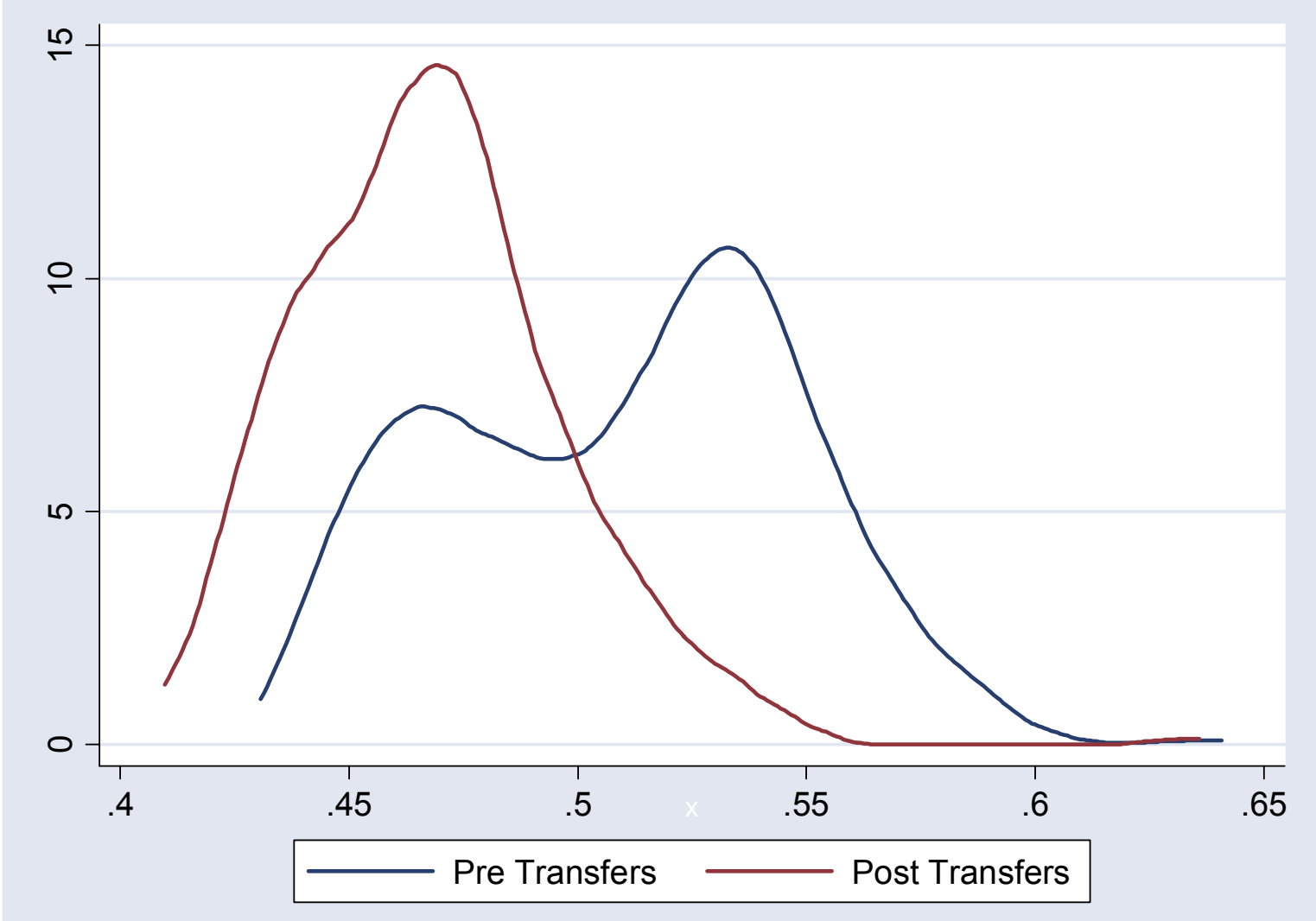


Table 1. Poverty-Reduction Transfers by Region

\begin{tabular}{|c|c|c|c|c|c|c|c|c|c|c|c|c|}
\hline \multirow[b]{2}{*}{ Region } & \multicolumn{4}{|c|}{ Family Subsidy ${ }^{A}$} & \multicolumn{4}{|c|}{ Unemployment $^{\mathrm{A}}$} & \multicolumn{4}{|c|}{ Assistance Pensions ${ }^{A}$} \\
\hline & Recipients $^{\dagger}$ & Share $^{\ddagger}$ & Amount* & Average $^{\star *}$ & Recipients $^{\dagger}$ & Share $^{\ddagger}$ & Amount* & Average** & Recipients $^{\dagger}$ & Share ${ }^{\ddagger}$ & Amount* & Average $^{\star \star}$ \\
\hline I & 19,122 & $4.50 \%$ & $\$ 76,603$ & $\$ 4,006$ & 135 & $0.03 \%$ & $\$ 1,524$ & $\$ 11,291$ & 6,249 & $1.47 \%$ & $\$ 282,220$ & $\$ 45,163$ \\
\hline II & 15,454 & $3.21 \%$ & $\$ 61,169$ & $\$ 3,958$ & 47 & $0.01 \%$ & $\$ 540$ & $\$ 11,498$ & 5,862 & $1.22 \%$ & $\$ 263,641$ & $\$ 44,975$ \\
\hline III & 18,328 & $7.24 \%$ & $\$ 74,011$ & $\$ 4,038$ & 70 & $0.03 \%$ & $\$ 797$ & $\$ 11,388$ & 5,980 & $2.36 \%$ & $\$ 270,571$ & $\$ 45,246$ \\
\hline IV & 50,402 & $8.36 \%$ & $\$ 200,837$ & $\$ 3,985$ & 149 & $0.02 \%$ & $\$ 1,716$ & $\$ 11,514$ & 20,273 & $3.36 \%$ & $\$ 920,557$ & $\$ 45,408$ \\
\hline V & 81,648 & $5.33 \%$ & $\$ 326,416$ & $\$ 3,998$ & 519 & $0.03 \%$ & $\$ 6,053$ & $\$ 11,663$ & 32,502 & $2.12 \%$ & $\$ 1,461,835$ & $\$ 44,977$ \\
\hline VI & 52,494 & $6.77 \%$ & $\$ 208,443$ & $\$ 3,971$ & 114 & $0.01 \%$ & $\$ 1,297$ & $\$ 11,374$ & 23,730 & $3.06 \%$ & $\$ 1,065,764$ & $\$ 44,912$ \\
\hline VII & 100,010 & $11.05 \%$ & $\$ 396,176$ & $\$ 3,961$ & 144 & $0.02 \%$ & $\$ 1,651$ & $\$ 11,468$ & 30,825 & $3.40 \%$ & $\$ 1,388,065$ & $\$ 45,030$ \\
\hline VIII & 180,915 & $9.73 \%$ & $\$ 717,320$ & $\$ 3,965$ & 544 & $0.03 \%$ & $\$ 6,266$ & $\$ 11,517$ & 77,195 & $4.15 \%$ & $\$ 3,450,309$ & $\$ 44,696$ \\
\hline IX & 109,755 & $12.65 \%$ & $\$ 447,964$ & $\$ 4,081$ & 190 & $0.02 \%$ & $\$ 2,270$ & $\$ 11,949$ & 54,944 & $6.33 \%$ & $\$ 2,490,582$ & $\$ 45,329$ \\
\hline$x$ & 117,391 & $11.01 \%$ & $\$ 471,432$ & $\$ 4,016$ & 203 & $0.02 \%$ & $\$ 2,358$ & $\$ 11,617$ & 56,699 & $5.32 \%$ & $\$ 2,570,569$ & $\$ 45,337$ \\
\hline$X I$ & 8,732 & $9.70 \%$ & $\$ 35,546$ & $\$ 4,071$ & 9 & $0.01 \%$ & $\$ 109$ & $\$ 12,056$ & 4,144 & $4.61 \%$ & $\$ 187,565$ & $\$ 45,262$ \\
\hline XII & 3,296 & $2.23 \%$ & $\$ 13,059$ & $\$ 3,962$ & 29 & $0.02 \%$ & $\$ 342$ & $\$ 11,776$ & 2,107 & $1.43 \%$ & $\$ 96,191$ & $\$ 45,653$ \\
\hline XIII & 196,350 & $3.25 \%$ & $\$ 799,425$ & $\$ 4,071$ & 1,475 & $0.02 \%$ & $\$ 16,768$ & $\$ 11,368$ & 103,829 & $1.72 \%$ & $\$ 4,672,439$ & $\$ 45,001$ \\
\hline Total & 953,897 & $6.34 \%$ & $\$ 3,828,403$ & $\$ 4,013$ & 3,628 & $0.02 \%$ & $\$ 41,691$ & $\$ 11,491$ & 424,339 & $2.82 \%$ & $\$ 19,120,309$ & $\$ 45,059$ \\
\hline
\end{tabular}

\begin{tabular}{|c|c|c|c|c|c|c|c|c|c|}
\hline \multirow[b]{2}{*}{ Region } & \multicolumn{4}{|c|}{ Solidarity Subsidy ${ }^{\mathrm{B}}$} & \multicolumn{4}{|c|}{ Water Subsidy ${ }^{\mathrm{B}}$} & \multirow[b]{2}{*}{ Expected Value of Subsidy } \\
\hline & Recipients $^{\dagger}$ & Share ${ }^{\ddagger}$ & Amount* & Average $^{\star *}$ & Recipients $^{\dagger}$ & Share $^{\ddagger}$ & Amount* & Average** & \\
\hline 1 & 1,690 & $1.51 \%$ & $\$ 16,739$ & $\$ 9,905$ & 32,595 & $29.14 \%$ & $\$ 181,758$ & $\$ 5,576$ & $\$ 1,317$ \\
\hline II & 910 & $0.73 \%$ & $\$ 8,749$ & $\$ 9,615$ & 37,787 & $30.45 \%$ & $\$ 276,450$ & $\$ 7,316$ & $\$ 1,267$ \\
\hline III & 1,683 & $2.45 \%$ & $\$ 16,425$ & $\$ 9,760$ & 25,355 & $36.91 \%$ & $\$ 87,661$ & $\$ 3,457$ & $\$ 1,775$ \\
\hline IV & 1,809 & $1.08 \%$ & $\$ 17,837$ & $\$ 9,860$ & 43,160 & $25.86 \%$ & $\$ 169,403$ & $\$ 3,925$ & $\$ 2,173$ \\
\hline V & 4,559 & $1.03 \%$ & $\$ 45,113$ & $\$ 9,895$ & 81,311 & $18.45 \%$ & $\$ 315,421$ & $\$ 3,879$ & $\$ 1,408$ \\
\hline VI & 2,562 & $1.20 \%$ & $\$ 24,642$ & $\$ 9,618$ & 33,872 & $15.81 \%$ & $\$ 90,136$ & $\$ 2,661$ & $\$ 1,792$ \\
\hline VII & 4,900 & $1.94 \%$ & $\$ 47,824$ & $\$ 9,760$ & 63,292 & $25.10 \%$ & $\$ 133,662$ & $\$ 2,112$ & $\$ 2,173$ \\
\hline VIII & 6,612 & $1.31 \%$ & $\$ 65,342$ & $\$ 9,882$ & 103,670 & $20.61 \%$ & $\$ 368,358$ & $\$ 3,553$ & $\$ 2,478$ \\
\hline IX & 3,815 & $1.60 \%$ & $\$ 38,189$ & $\$ 10,010$ & 52,692 & $22.11 \%$ & $\$ 139,084$ & $\$ 2,640$ & $\$ 3,595$ \\
\hline$x$ & 4,881 & $1.65 \%$ & $\$ 48,541$ & $\$ 9,945$ & 50,919 & $17.21 \%$ & $\$ 194,525$ & $\$ 3,820$ & $\$ 3,083$ \\
\hline$X I$ & 371 & $1.44 \%$ & $\$ 3,710$ & $\$ 10,000$ & 9,253 & $36.01 \%$ & $\$ 47,448$ & $\$ 5,128$ & $\$ 3,049$ \\
\hline XII & 528 & $1.22 \%$ & $\$ 5,134$ & $\$ 9,723$ & 8,612 & $19.93 \%$ & $\$ 28,475$ & $\$ 3,307$ & $\$ 971$ \\
\hline XIII & 9,898 & $0.60 \%$ & $\$ 96,938$ & $\$ 9,794$ & 109,236 & $6.59 \%$ & $\$ 251,741$ & $\$ 2,305$ & $\$ 966$ \\
\hline Total & 44,218 & $1.07 \%$ & $\$ 435,184$ & $\$ 9,842$ & 651,752 & $15.74 \%$ & $\$ 2,284,122$ & $\$ 3,505$ & $\$ 1,708$ \\
\hline
\end{tabular}


Table 2. Changes in Income Inequality by Region

\begin{tabular}{|c|c|c|c|c|c|c|c|c|c|c|c|c|c|}
\hline & $\underset{\text { I }}{\text { Region }}$ & $\begin{array}{r}\text { Region } \\
\text { II }\end{array}$ & $\begin{array}{r}\text { Region } \\
\text { III }\end{array}$ & $\begin{array}{r}\text { Region } \\
\text { IV }\end{array}$ & $\begin{array}{r}\text { Region } \\
\text { V }\end{array}$ & $\begin{array}{r}\text { Region } \\
\text { VI }\end{array}$ & $\begin{array}{r}\text { Region } \\
\text { VII }\end{array}$ & $\begin{array}{r}\text { Region } \\
\text { VIII }\end{array}$ & $\begin{array}{r}\text { Region } \\
\text { IX }\end{array}$ & $\begin{array}{r}\text { Region } \\
\text { R }\end{array}$ & $\begin{array}{r}\text { Region } \\
\text { XI }\end{array}$ & $\begin{array}{r}\text { Region } \\
\text { XII }\end{array}$ & $\begin{array}{r}\text { Region } \\
\text { XIII }\end{array}$ \\
\hline Counties & 10 & 9 & 9 & 15 & 38 & 33 & 30 & 52 & 31 & 42 & 10 & 11 & 52 \\
\hline \multicolumn{14}{|c|}{ Pre-Transfer Income Inequality } \\
\hline Maximum & 0.544 & 0.501 & 0.531 & 0.541 & 0.492 & 0.487 & 0.540 & 0.641 & 0.587 & 0.577 & 0.574 & 0.561 & 0.556 \\
\hline Minimum & 0.527 & 0.475 & 0.508 & 0.467 & 0.445 & 0.439 & 0.483 & 0.510 & 0.521 & 0.495 & 0.533 & 0.517 & 0.442 \\
\hline Average & 0.534 & 0.489 & 0.519 & 0.507 & 0.460 & 0.458 & 0.507 & 0.548 & 0.549 & 0.532 & 0.556 & 0.538 & 0.489 \\
\hline \multicolumn{14}{|c|}{ Change in Estimated Gini } \\
\hline Average & $-9.43 \%$ & $-4.84 \%$ & $-9.06 \%$ & $-8.83 \%$ & $-4.41 \%$ & $-6.15 \%$ & $-10.03 \%$ & $-11.84 \%$ & $-11.85 \%$ & $-11.38 \%$ & $-11.02 \%$ & $-3.48 \%$ & $-2.63 \%$ \\
\hline Std. Dev. & $0.358 \%$ & $0.311 \%$ & $0.324 \%$ & $0.678 \%$ & $0.154 \%$ & $0.430 \%$ & $0.729 \%$ & $1.944 \%$ & $0.810 \%$ & $0.885 \%$ & $0.299 \%$ & $0.138 \%$ & $0.973 \%$ \\
\hline $\begin{array}{l}\text { Counties w/ Different } \\
\text { Gini }(90 \% \\
\text { confidence) }\end{array}$ & 10 & 6 & 9 & 15 & 37 & 32 & 30 & 50 & 31 & 42 & 9 & 2 & 43 \\
\hline $\begin{array}{l}\text { Counties w/ Different } \\
\text { Gini }(95 \% \\
\text { confidence) }\end{array}$ & 10 & 6 & 9 & 15 & 36 & 31 & 30 & 50 & 31 & 42 & 8 & 1 & 40 \\
\hline $\begin{array}{l}\text { Counties w/ Different } \\
\text { Gini }(99 \% \\
\text { confidence) }\end{array}$ & 6 & 3 & 8 & 15 & 30 & 29 & 30 & 50 & 31 & 42 & 6 & 0 & 38 \\
\hline
\end{tabular}


Table 3. Changes in Inequality by Inequality Decile

\begin{tabular}{|c|c|c|c|c|c|}
\hline & \multicolumn{5}{|c|}{ Percentile, Post Transfer } \\
\hline & 1 & 2 & 3 & 4 & 5 \\
\hline \multirow{5}{*}{ 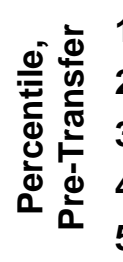 } & 84 & 16 & 0 & 0 & $c$ \\
\hline & 15 & 38 & 29 & 16 & 2 \\
\hline & 1 & 43 & 25 & 13 & 18 \\
\hline & 0 & 3 & 46 & 38 & 13 \\
\hline & 0 & 0 & 0 & 42 & 6 \\
\hline
\end{tabular}




\section{DAVIDSON INSTITUTE WORKING PAPER SERIES - Most Recent Papers}

The entire Working Paper Series may be downloaded free of charge at: www.wdi.umich.edu

CURRENT AS OF 05/11/07

\begin{tabular}{|c|c|c|}
\hline Publication & Authors & Date \\
\hline $\begin{array}{l}\text { No. 872: Local Distributional Effects of Government Cash Transfers in } \\
\text { Chile }\end{array}$ & $\begin{array}{l}\text { Claudio A. Agostini and Philip } \\
\text { Brown }\end{array}$ & May 2007 \\
\hline $\begin{array}{l}\text { No. 871: How do Workers Fare During Transition?Perceptions of Job } \\
\text { Insecurity among Russian Workers, 1995-2004 }\end{array}$ & $\begin{array}{l}\text { Susan J. Linz and Anastasia } \\
\text { Semykina }\end{array}$ & April 2007 \\
\hline $\begin{array}{l}\text { No. 870: Does Reform Work? An Econometric Examination of the } \\
\text { Reform-Growth Puzzle }\end{array}$ & Ian Babetskii and Nauro Campos & April 2007 \\
\hline No. 869: Perceptions and Behavior: Analyzing Wage Arrears in Russia & $\begin{array}{l}\text { Susan Linz, Anastasia Semykina } \\
\text { and Charles Petrin }\end{array}$ & June 2006 \\
\hline $\begin{array}{l}\text { No. 868: The Endogeneity of Association Agreements and their Impact } \\
\text { on Trade for Eastern Countries: Empirical Evidence for Romania }\end{array}$ & $\begin{array}{l}\text { Christophe Rault, Ana Maria Sova } \\
\text { and Robert Sova }\end{array}$ & April 2007 \\
\hline $\begin{array}{l}\text { No. 867: Institutions \& Entrepreneurship Development in Russia: A } \\
\text { Comparative Perspective }\end{array}$ & $\begin{array}{l}\text { Saul Estrin, Ruta Aidis and } \\
\text { Tomasz Mickiewicz }\end{array}$ & Feb 2007 \\
\hline No. 866: Dutch Disease Scare in Kazakhstan: Is it real? & Balázs Égert and Carol S. Leonard & $\begin{array}{l}\text { March } \\
2007\end{array}$ \\
\hline $\begin{array}{l}\text { No. 865: Minimum Wage and Tax Evasion: Theory } \\
\text { and Evidence }\end{array}$ & Mirco Tonin & Jan 2007 \\
\hline $\begin{array}{l}\text { No. 864: Dynamics of the Financial Wealth of the Institutional Sectors in } \\
\text { Bulgaria: Empirical Studies of the Post-Communist Period }\end{array}$ & $\begin{array}{l}\text { Nikolay Nenovsky and Gergana } \\
\text { Mihaylova }\end{array}$ & $\begin{array}{l}\text { March } \\
2007\end{array}$ \\
\hline $\begin{array}{l}\text { No. 863: Impact of Derivatives Trading on Emerging Capital Markets: A } \\
\text { Note on Expiration Day Effects in India }\end{array}$ & $\begin{array}{l}\text { Sumon Kumar Bhaumik and } \\
\text { Suchismita Bose }\end{array}$ & $\begin{array}{l}\text { March } \\
2007\end{array}$ \\
\hline $\begin{array}{l}\text { No. 862: Short- \& Medium- Term Determinants of Current Account } \\
\text { Balances in Middle East \& North Africa Countries }\end{array}$ & Aleksander Aristovnik & $\begin{array}{l}\text { March } \\
2007\end{array}$ \\
\hline $\begin{array}{l}\text { No. 861: Time-Varying Comovements in Developed and Emerging } \\
\text { European Stock Markets: Evidence from Intraday Data }\end{array}$ & Balázs Égert and Evžen Kočenda & $\begin{array}{c}\text { March } \\
2007\end{array}$ \\
\hline $\begin{array}{l}\text { No: 860: Giving Children a Better Start: Preschool Attendance \& } \\
\text { School-Age Profiles }\end{array}$ & $\begin{array}{l}\text { Sam Berlinski, Sebastian Galiani } \\
\text { and Marco Manacorda }\end{array}$ & Jan 2007 \\
\hline $\begin{array}{l}\text { No. 859: Real Exchange Rates in Small open OECD \& Transition } \\
\text { Economies: Comparing Apples with Oranges? }\end{array}$ & $\begin{array}{l}\text { Balázs Égert, Kirsten } \\
\text { Lommatzsch and Amina } \\
\text { Lahreche-Revil }\end{array}$ & Jan 2007 \\
\hline $\begin{array}{l}\text { No. 858: Is Education the Panacea for Economic Deprivation of } \\
\text { Muslims? Evidence from Wage Earners in India, 1987-2004 }\end{array}$ & $\begin{array}{l}\text { Sumon Kumar Bhaumik and } \\
\text { Manisha Chakrabarty }\end{array}$ & Jan 2007 \\
\hline $\begin{array}{l}\text { No. 857: Human Capital, Economic Growth, and Regional Inequality in } \\
\text { China }\end{array}$ & $\begin{array}{l}\text { Belton Fleisher, Haizheng Li and } \\
\text { Min Qiang Zhao }\end{array}$ & Jan 2007 \\
\hline $\begin{array}{l}\text { No. 856: Does Better Environmental Performance Affect Revenues, } \\
\text { Costs, or Both? Evidence From a Transition Economy }\end{array}$ & $\begin{array}{l}\text { Dietrich Earnhart and Lubomir } \\
\text { Lizal }\end{array}$ & Feb 2007 \\
\hline No. 855: Media Coverage \& Charitable Giving After the 2004 Tsunami & Philip Brown and Jessica Minty & Dec 2006 \\
\hline $\begin{array}{l}\text { No. 854: Default Rates in the Loan Market for SMEs: Evidence from } \\
\text { Slovakia }\end{array}$ & $\begin{array}{l}\text { Jarko Fidrmuc, Christa Hainz and } \\
\text { Anton Maleisch }\end{array}$ & Nov 2006 \\
\hline $\begin{array}{l}\text { No. 853: Monetary Policy before Euro Adoption: Challenges for EU } \\
\text { New Members }\end{array}$ & $\begin{array}{l}\text { Jan Filáček, Roman Horváth and } \\
\text { Michal Skorepa }\end{array}$ & Nov 2006 \\
\hline $\begin{array}{l}\text { No. 852: Private-Sector Credit in Central \& Eastern Europe: New } \\
\text { (Over) Shooting Stars? }\end{array}$ & $\begin{array}{l}\text { Balázs Égert, Peter Backé and } \\
\text { Tina Zumer }\end{array}$ & Nov 2006 \\
\hline $\begin{array}{l}\text { No. 851: Interest Rate Pass-Through in Central \& Eastern Europe: } \\
\text { Reborn from Ashes Merely to Pass Away? }\end{array}$ & $\begin{array}{l}\text { Balázs Égert,Jesus Crespo- } \\
\text { Cuaresma and Thomas Reininger }\end{array}$ & Nov 2006 \\
\hline $\begin{array}{l}\text { No. 850: Monetary Transmission Mechanism in Central \& Eastern } \\
\text { Europe: Gliding on a Wind of Change }\end{array}$ & $\begin{array}{l}\text { Fabrizio Coricelli, Balázs Égert } \\
\text { and Ronald MacDonald }\end{array}$ & Nov 2006 \\
\hline No. 849: Crime Distribution \& Victim behavior During a Crime Wave & $\begin{array}{l}\text { Rafael Di Tella, Sebastian Galiani } \\
\text { and Ernesto Schargrodsky }\end{array}$ & Nov 2006 \\
\hline
\end{tabular}

